The approach to meal planning in the new 'home-making' scheme of work is more realistic and arouses greater interest than the old approach by way of the principles of cookery. We must not be too satisfied, however, with results attained so far; we must go on endeavouring to teach more about nutrition-and that more, better-and to continue to take advantage of research in the chemistry and physiological values of food.

\title{
Nutrition in Adult Education
}

\section{By R. C. GARRY, Department of Physiology, University College, Dundee, University of St Andrews}

Adult education in any form differs markedly from the education provided in childhood and in adolescence. In adult education compulsion cannot be applied, and, in Scotland at least, there are no examinations and no rewards in the form of certificates or diplomas. Success depends on the intrinsic attractiveness or usefulness of the topic under discussion. In theory such a system is ideal; the possession of new knowledge is sufficient reward for the labour involved in acquiring it. But all tutors of adult education classes know that the great majority of their pupils do hanker after some tangible evidence of the time they have spent studying in the class.

\section{Nutrition as a topic for adult education}

The importance and possibilities of nutrition as a suitable topic were not realized at first in the adult education movement as a whole. Initially there was a tendency for a strong sociological, even political, bias to influence the various organizations which busied themselves with adult education.

When local education authorities and universities began to play a part in adult education, however, emphasis was laid, as a corrective perhaps, on 'useless' knowledge, or on purely recreational studies. The confessedly utilitarian was regarded with suspicion, and classes dealing with human physiology and hygiene had to face opposition born of squeamishness. Until physiology is taught there can be no proper teaching of nutrition. The West of Scotland Joint Committee on Adult Education, with much misgiving, first sponsored a course of ten lecture-demonstrations on human physiology in 1927. Even in $1946-7$, only six of the 157 courses conducted by that Committee deal with human biology, and there is no course on nutrition as such.

On the other hand, we have had for a long time organizations wholly interested in food and in nutrition, many of them, unfortunately, anything but scientific. For the cold-blooded scientific study of nutrition is new; witness the genealogical tree at the beginning of Graham Lusk's The Science of Nutrition (Lusk, 1928). The realization that such knowledge must be passed on to our adult population is newer still.

The Food Education Society, founded in 1908 as The National Food Reform Association, was well before its time; still a power in the land, this society has many desirable reforms to its credit, but it may be doubted if these reforms were brought about by education of the people primarily concerned, namely, the citizens of this country. 
Much later came a somewhat similar organization, the Childrens' Nutrition Council, founded in 1934 as a political pressure group to promote certain legislative and administrative reforms. Education in nutrition was no more than an important sideline, and the bulletin of the Childrens' Nutrition Council is now to be merged into a nutrition pamphlet produced by the Central Council for Health Education.

We may take it that the Central Council for Health Education and its counterpart the Scottish Council for Health Education, will, in the future, carry much of the burden of this type of adult education in nutrition. In somewhat similar fashion the Scottish Youth Leadership Training Association (S.Y.L.T.A.) tries to influence the impressionable adolescent and pays some attention to nutrition. The British Association for the Advancement of Science, especially in the years before the war, frequently devoted time to the discussion of nutrition problems.

It is doubtful whether such organizations will ever directly reach the man and woman in the street in large numbers. It was really the sociological bombshell of Sir John Orr's Food, Health and Income (Orr, 1937), and the struggle against starvation in the Second German War, which made the public as a whole 'nutrition-conscious' and which wrenched adult education in nutrition right out of the hands of scholastic and academic educationists. The nation could not afford to wait, and one wonders if the nation can afford to wait in other branches of adult education also.

During the war the Army Bureau of Current Affairs (A.B.C.A.), with its pamphlets and the talks based on these pamphlets, reached millions of service men and women. Three, out of a total of 118 pamphlets, numbers 4,18 , and 65 , dealt with food and nutrition. The successor to A.B.C.A., the Bureau of Current Affairs, started a new series of pamphlets with Food and Famine by Le Gros Clark (1946) and continues with a very recent map review dealing with food. During the war, too, itinerant speakers, under the auspices of the scheme for adult education in H.M. Forces, frequently talked about nutrition.

At the same time, education of the civilian population in nutrition was carried on in rather hesitant and sporadic fashion by the British Broadcasting Corporation, but with set purpose and massive drive by the Ministry of Food. The Public Relations Division and the Food Advice Division of that Ministry, by posters, leaflets, pamphlets, Food Advice Centres, and 'Food Leaders', reached out to the civilian population. Incidentally, the Ministry of Food has a better understanding of human psychology than the Joint Committees for adult education; the Ministry gives a badge to 'Food Leaders' who reach a certain degree of competence.

In comparison with this campaign of the Ministry of Food all other branches of adult education, in any subject, pale into insignificance. Nutrition, once the Cinderella of adult education, by its intrinsic importance, by the force of war, has outstripped all other topics.

\section{The technique of adult education in nutrition}

There must be many, especially the pedagogues among us, who are left breathless and drenched by the torrent of propaganda and education in nutrition during these past 7 years. Many of us wonder if the time is not ripe for a critical appraisal of future policy. 
In the field of propaganda, in the power to arouse interest, the Ministry of Food is supreme. Yet all its power and resources will be needed for years to come to hold in check, and to reform, undesirable 'food folkways'. To change food habits is no easy task. The problem has recently been discussed by Le Gros Clark (I944).

Propaganda alone, however necessary, can never take the place of real education, education based on knowledge and understanding of the basic scientific facts of nutrition. Adult education in nutrition must start with proper instruction in general science and, above all, in human physiology. No better use could be found for part of the additional year at school so soon to come into operation. We must, however, face the fact that such school instruction is not yet in being; there are few school teachers properly versed in human biology, and, even in the future, such school instruction will rarely carry over effectively into adult life. Continuous supplementation will be required in later years. Once the basic facts are acquired, interest in nutrition must be kept alive. This, no doubt, the Ministry of Food will endeavour to do, but it is to be hoped that there will still be room for the set adult education course in nutrition.

\section{Set lecture courses}

Such courses should follow an introductory course in human physiology or in biology, since nutrition cannot be understood if studied alone. In default of such an introductory course, the class in nutrition must supply its own physiological teaching.

This is a golden opportunity for the committees who control adult education. Public interest in nutrition has been aroused. But this interest must be retained in the face of severe and constant competition. In the past, at least, the adult education tutor had to drag his pupils away from a warm fireside, after a heavy day's work, into the wet and foggy streets and then guide them successfully past the enticing lights of cinema, music-hall, public house and billiard saloon; and then, more often than not, the pilgrimage ended in the uninviting atmosphere of a day-school classroom evoking all the healthy antipathies of an adult for his school days. The meeting-place should never, never be in a day-school. The break between school days and adult education should be as complete as possible. Probably the best meeting room is a university classroom, since universities still have some slight prestige value in the community.

In the course itself there must be first-class exposition. Adult students will not put up with the halting delivery and the excessive doubts and hesitations which university students have to suffer from some of their teachers. A reasonable degree of dogmatism may stimulate rather than suppress healthy discussion. All possible adventitious aids must be used, diagrams, lantern slides, films and demonstrations. Tables of food values, an inevitable feature, one might almost say a scourge, of classes in nutrition, are most unsatisfactory. Students should be told how to use such tables, copies should be available for reference and exercises may be based on them.

Classes in cookery, an important aspect of adult education, give great scope for instruction in nutrition. Domestic dietetics, for that is what cookery is, cannot be properly studied apart from a background of nutritional knowledge. The Ministry of Food is already doing such work, but the more formal adult education movement could take it up with advantage. 


\section{Text-books}

There remains the problem of the text-book in adult education. This problem is not peculiar to adult classes in nutrition alone. Good text-books for the adult are very rare. At present they either smack of the school or university text-book designed to prepare the reader for examinations, or concentrate on the sensational and spectacular in a vain attempt to compete with the trivial forms of fiction. Many of the cheaper, recent 'popular' books on nutrition are not free from the latter vice. Parenthetically, why do writers of cookery books not introduce more nutrition into their books of recipes? Terry (1944) makes a successful attempt to do so. Cookery is the 'practical work' of the class in nutrition.

Very rarely are the usual texts for students of medicine or of dietetics of value in adult education work. Authors and publishers will have to realize that the book on nutrition suitable for the adult public is a book by itself. Such books must be reasonably priced if they are to reach, as they ought, the majority of homes in the country. At present, almost without exception, they are far too dear.

But there are exceptions. Benn's Sixpenny Library published a tiny book by Macfie (1927) on human physiology, and in the following year Nutrition and Dietetics by Cathcart (1928). Both are good examples of books designed deliberately for widescale adult education. They avoid sensationalism and have dignity. Penguin Books, in more recent times, have published Our Food Problem by Le Gros Clark (1939), Food, the Deciding Factor by Wokes (1941) and Health of the Future by A. Bourne (1942). In India, Masani (1944) wrote Your Food. A Study of the Problem of Food and Nutrition in India, an excellent book, costing only one rupee. The Scottish Youth Leadership Training Association has a shilling pamphlet, Health Talks for Boys, which has a fair amount of information on nutrition. The best of all such recent texts for the purposes of adult education is undoubtedly the Ministry of Food's Manual of Nutrition by Pyke (1945). It has just enough about the physiology of digestion, absorption and metabolism, it gives practical exercises, it has simple diagrams and it has questions to test the information acquired by the reader. The price is again one shilling. Somewhat more expensive are the books by G. Bourne (1942), Orr (1943), Bacharach (1945), Mottram (1940), Taylor (1944), and the Council of British Societies for Relief Abroad (1945). Food Values at a Glance, by Plimmer (1935, 1940) is probably the first successful attempt to overcome for the man in the street the complexities of the usual food tables.

No adult education class is complete without a class library. Here the more expensive book may find a place on the shelves. They need no longer be text-books of the usual type. Such are the books by Harris (1937), Kermack \& Eggleton (1938), Crawford \& Broadley (1938), Drummond \& Wilbraham (1939), McCollum, OrentKeiles \& Day (1939), Sherman \& Lanford (1943), and Cruickshank (1946).

Public interest is aroused, the public is waiting; will those responsible for the adult education movement rise to the occasion? 


\section{REFERENCES AND ADDRESSES OF SOCIETIES}

Bacharach, A. L. (1945). Science and Nutrition. London: Watts and Co.

Bourne, A. (1942). Health of the Future. London: Penguin Books Limited.

Bourne, G. (1942). War-time Food for Mother and Child. London: Oxford University Press.

British Association for the Advancement of Science. Burlington House, London, W. I.

Bureau of Current Affairs. Carnegie House, I I7 Piccadilly, London, W. I.

Cathcart, E. P. (1 928). Nutrition and Dietetics. London: Ernest Benn.

Central Council for Health Education. Tavistock House, Tavistock Square, London, W.C. I.

Childrens' Nutrition Council. 6 East Common, Harpenden, Herts, England.

Clark, F. Le Gros (1939). Our Food Problem. London: Penguin Books Limited.

Clark, F. Le Gros (1944). Lancet, 247, 53.

Clark, F. Le Gros (1946). Food and Famine. London: Bureau of Current Affairs.

Council of British Societies for Relief Abroad (1945). Nutrition and Relief Work. A Handbook for the Guidance of Relief Workers. London: Humphrey Milford.

Crawford, W. \& Broadley, H. (1938). The People's Food. London: Heinemann.

Cruickshank, E. W. H. (1938). Food and Physical Fitness. Edinburgh: Livingstone.

Cruickshank, E. W. H. (1946). Food and Nutrition; The Physiological Basis of Human Nutrition. Edinburgh: Livingstone.

Drummond, J. C. \& Wilbraham, A. (1939). The Englishman's Food. A History of Five Centuries of English Diet. London: Cape.

Food Education Society. 33 Gordon Square, London, W.C. I.

Harris, L. J. (1937). Vitamins in Theory and Practice. New York: The Macmillan Co.

Kermack, W. O. \& Eggleton, P. (1938). The Stuff We're Made Of. London: Edward Arnold.

Lusk, G. (1928). The Science of Nutrition. New York: The Saunders Co.

McCollum, E. V., Orent-Keiles, E. \& Day, H. G. (1939). The Newer Knowledge of Nutrition. New York: The Macmillan Co.

Macfie, R. C. (1927). The Body. An Introduction to Physiology. London: Ernest Benn.

Masani, M. R. (1944). Your Food. A Study of the Problem of Food and Nutrition in India. Bombay: Padma Publications.

Mottram, V. H. (1940). Healthy Eating. London: Cassell and Co.

Orr, J. B. (1937). Food, Health and Income. London: Macmillan and Co.

Orr, J. B. (1943). Food and the People. Target for Tomorrow. No. III. London: Pilot Press.

Plimmer, V. G. (1935, 1940). Food Values at a Glance and How to Plan a Healthy Diet. London: Longmans, Green and Co.

Pyke, M. (1945). A Manual of Nutrition. London: Ministry of Food, H.M.S.O.

Scottish Council for Health Education. 3 Castle Street, Edinburgh 2.

Scottish Youth Leadership Training Association, 57 Melville Street, Edinburgh 3.

Scottish Youth Leadership Training Association (1944). Health Talks for Boys.

Sherman, H. C. \& Lanford, C. S. (1943). Essentials of Nutrition. London: Macmillan.

Taylor, S. (1944). Battle for Health. A Primer for Social Medicine. London: Nicholson and Watson.

Terry, J. (1944). Food without Fuss. London: Faber and Faber.

Wokes, F. (194I). Food, the Deciding Factor. London: Penguin Books Limited.

\section{The Teaching of Nutrition to Medical Students}

\section{By L. S. P. Davidson, Department of Medicine, University of Edinburgh}

Although nearly 20 years have elapsed since I first organized a course of instruction for final-year medical students in Aberdeen on the physiology of nutrition and the practical application of dietetics for the prevention and treatment of disease, it is only within the past month that I have realized the necessity of viewing this educational problem from a much broader angle. Instruction in matters pertaining to nutrition is given in many departments of the faculty of medicine, and the best results will only be obtained if the curriculum in each department is fitted into a carefully thought-out and co-ordinated plan. Before such a co-ordinated course can be planned it is necessary 